\title{
The Johann Jacob Wepfer Award 2013
}

\section{THE JOHANN JACOB WEPFER AWARD}

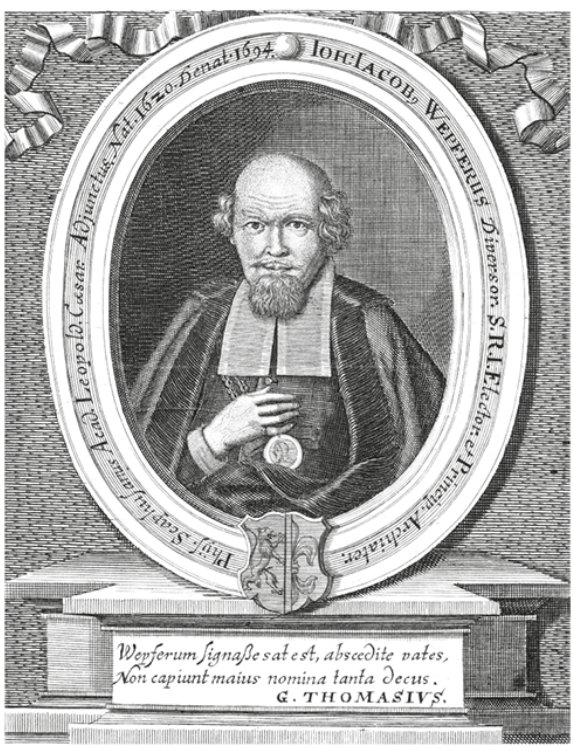

fff?
THE JOHANN JACOB WEPFER AWARD OF THE

European Stroke CONFERENCE 2013 IS DEDICATED TO

PROF. HANS-CHRISTOPH DIENER, MD ESSEN, GERMANY

AND

PROF. WERNER HACKE, MD HEIDELBERG, GERMANY

FOR OUTSTANDING WORK IN

THE FIELDS OF PREVENTIVE STROKE MANAGEMENT AND ACUTE STROKE TREATMENT

LONDON, MAY 29 ${ }^{\text {TH }}, 2013$

J. M. FERRO 